Araştırma Makalesi / Research Article

\title{
TOKAT AĞZINDA BAZI ZARFLARLA ZARF YAPICI EK VE EDATLAR
}

\author{
Erol ÖZTÜRK*
}

\section{SOME ADVERBS AND ADVERB CREATING SUFFIXES AND PREPOSITIONS İN TOKAT DİALECTS}

\author{
$\ddot{O} z$
}

Zarf-fiil eki almış fiiller ve bir isimle bir edatın birleşmesiyle oluşan edat grupları cümlede genellikle zarf görevi yapar. Zarf-fiil eklerinin eklendiği fiillerden oluşan zarflar, bu eklerin vurgulu unsurlar olmas1 sebebiyle genişlemeye uğramaktadır. Genişlemeyi sağlayan pekiştirici unsurlar bazen ses, bazen ek, bazen de bir edat olabilir. Zarf olarak kullanılan edat gruplarında da benzer durumla karşılaşılır. Anadolu ağızlarının pek çoğunda farklı zarf unsurları görülmekte ya da standart Türkiye Türkçesinin zarf unsurları ağızlarda farklı biçimler almaktadır. Tokat ağzında zarf unsurlarının farklı yapıları, zarf-fiil eklerinin pekiştirici morfemlerle genişlemesi ve Eski Türkçe döneminde kullanılan bazı edatların aynen ya da az değişiklikle kullanılması dikkat çeken özelliklerdir. Bu çalışmada Tokat ağzında bulunan zarflar, zarf yapıcı ek ve edatlar ele alınmıştır. Zarf-fiil ekleriyle yapılan zarfların yapısal özellikleri kaynak eserler ışı̆̆ında incelenmiştir. Çalışmada verilen örnekler sözlü kaynaklara dayanır.

Anahtar Kelimeler: Zarf, Zarf-Fiil, Ek, Edat, Tokat Ağzı.

\begin{abstract}
Gerundium suffixed verbs and preposition groups which created by conjugation of preposition and noun, acts as a adverb in sentence. Adverbs consisting of verbs to which adverb-verb suffixes are added are expanded because these suffixes are emphasized elements. Consolidation elements what make dilatation sometimes can be suffix or prepositions. There is similar situation in prepositions of using as an adverb. Most of the Anatolian dialects contain different adverbs or standart Turkey Turkish's adverbs can see in dialects different structures. There is significant features of Tokat Dialects is different structures of adverb factors, gerundiums dilatation with boost morphems and some prepositions from old Anatolian Turkish keeps never changed or less changed. In this study, adverbs, adverbial suffixes and prepositions in Tokat dialect are discussed. The structural features opf adverbs made with adverb-verb affixes were examined in the light of source works. The examples given in the study are based on personel sources.
\end{abstract}

\footnotetext{
* Prof. Dr., Bolu Abant İzzet Baysal Üniversitesi, e-posta: ozturk@ibu.edu.tr, https://orcid.org/000-0001-6493-1443.

Makale Gönderim Tarihi: 11.09.2020 https://doi.org/10.11616/basbed.v20i58861.793857 Makale Kabul Tarihi : : 16.12.2020
} 
Keywords: Adverb, Gerundium, Suffix, Preposition, Tokat Dialect.

\section{Giriş}

Tokat ve çevresi 1071 Malazgirt Savaşı'ndan sonra Danişmendliler tarafından fethedilmiştir. 1080'den bugüne kadar Türk toprakları olan bölgenin Türkleşmesi bir fetih menkıbeleri destanı olan Danişmendnâme'de anlatılmaktadır. Danişmend Gâzi'nin Canik seferlerine çıktığ1, Trabzon Rum Devleti ve Gürcülerle Niksar yakınlarında çetin muharebeler yaptığ 1 bilinmektedir (Turan, 1993:129).

Tokat ve Niksar 1178 'de II. Kılıçaslan tarafından Selçuklu topraklarına katılmış, Anadolu Selçukluların etkisinin azalmasıyla bölgede önce İlhanlılar sonra da Eratnalılar dönemi başlamıştır.

Tokat'a ağırlıklı olarak Oğuz Türkleri yerleşmiştir. Sümer'in XVI. yy’da Anadolu'da Oğuz boylarına ait yer adları listesinde Tokat-Sivas bölgesinde Kayı (8), Bayat (1), Alka Evli (1), Yazır (1), Döger (2), Dodurga (2), Kızık (3), Karkın (8), Bayındır (1), Çavuldur (3), Çepni (3), Salur (8), Eymür (7), Alayunylu (3), İğdir (2), Büğdüz (2), Yıva (1) adları geçer (Sümer 1999: 405-427). İlhanlıların Anadolu'da hâkimiyetlerini güçlendirmek için bölgeye doğudan asker ve sivil halk getirdikleri bilinmektedir.

Tokat ili ağızları, Anadolu Ağızlarının Sınıflandırılması adlı eserde Batı Grubu ağızları içerisinde VI. Alt Grupta; Havza, Lâdik, Amasya, Mesudiye, Şebinkarahisar, Sivas (Şarkışla, Gemerek hariç), Alucra, Malatya, Hekimhan, Arapkir ağızlarıyla birlikte ele alınır (Karahan 1996a:117). Bölge ağızlarında kalın yuvarlak o, u ünlülerinin yarı kalın ó, ú şeklinde kullanılması, ḩ ve ñ ünsüzlerinin yaygın olması, şimdiki zaman kip ekinin -yo şeklinde görülmesi, r ünsüzünün düşmesi, ñ sesinin iki ünlü arasında yarı sızıcılaşması, istek kip ekinin 1.çokluk şahıslarda (gelek) yaygın olarak kullanılması gibi özellikler belirgindir (Karahan 1996a:168-170).

Tokat ili ağılarıyla ilgili ilk çalışma Ahmet Caferoğlu'nun Sivas ve Tokat Illeri Ağızlarından Toplamalar adlı eseridir. Caferoğlu, 1944 yılında daha çok Artova yöresinden olmak üzere Tokat Merkez, Turhal, Zile, Niksar, Reşadiye ve Erbaa'dan metinler derlemiştir. Sınırlı işaretlerle yazıya geçirilen metinlerin önemli bir kısmı şiirdir.

2006'da Necati Demir tarafindan neşredilen Tokat İli ve Yöresi Ağızları adlı eserde bölgeden derlenen 113 metin ses ve şekil bilgisi açısından incelenmiştir. Eserde Tokat yöresi ağızlarının ses ve şekil özellikleri on 
iki maddede sıralanmış, Kelkit nehrinin kuzeyinde ve güneyinde kalanlar olmak üzere iki ayrı ağız bölgesi tespit edilmiştir (Demir, 2006: 67).

Tokat bölgesi ağılarıyla ilgili olarak derleme ve inceleme tarzında bitirme tezleri vardır. Resmi Akkaya, Tokat A $\breve{g} z$, DTCF, 1970. Remzi

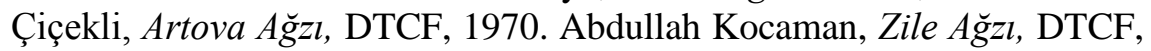
1970. Nermin Tekcan Zile ve Yöresi Ağızları Sözlüğü, DTCF, 1971, Münire Uçak Tokat Ağzı ve Folkloru, DTCF,1972. Turan Gümüş, Tokat A ğzından Derlemeler, DTCF, 1989. Orhan Çatak, Tokat Kazova Köyleri Ağız Araştırmaları, İstanbul Ü, 1976. Emin Ulu, Tokat-Almus Köyleri (Babaköyü, Çevreli, Ormandibi, Fenk) A $\breve{g}_{l z}$ Derlemesi, İstanbul Ü, 1978. Fahri Y1lmaz, Artova İlçesi Dil Özellikleri, Atatürk Ü, 1983. Murat İpek Tokat İli Turhal İlçesi Üçgözen Köyü Kumuk Ăgzl Atatürk Ü, 1983 (Gülensoy, Alkaya 2000).

\section{Tokat İli Ağızlarında Zarflar ve Zarf Yapıcı Unsurlar}

Söz diziminde cümleyi oluşturan ögelerden biri olarak zarflar, yalın ya da bazı hâl eklerini almış isimlerden ve zarf-fiil eki almış fiillerden oluşmaktadır (Karahan, 2004: 33). "Zarflar sıfatlardan daha az müstakil kavramlar ve bir kılışı veya bir vasfı değerlendirme ve açıklama işleyişinde kelimeler olduklarından söz içinde çoğunlukla bir kelime türü ile birlikte görülürler (Banguoğlu 1995: 371)." "Sifatlardan ve kendi türlerindeki kelimelerden önce gelmekle birlikte asıl bulundukları yer fiilin önüdür (Korkmaz 2003: 451)." Zarflar yalın durumda aslında birer addır. Sıfat ve adlara zarf niteliği kazandıran onların dildeki kullanılışları ve görevleridir (Korkmaz 2003: 451). Zarflar ad çekimi eki almazlar. Fakat bazı ad çekimi ekleri ad soyundan kelimelere eklenerek onları zarfa dönüştürürler. Adları zarfa dönüştüren çekim ekleri canlı çekim özelliğini yitirmiş, birleştiği adla kaynaşmışlardır (Korkmaz 2003: 451). Adlar cümle içinde bir edatla birlikte edat grubu yapısında zarf oluştururlar.

Karaağaç, eylemleri özel, aydın ve belirgin hâle getirmek için yani eyleme yükleme yapabilmek için bütün dünya dillerinde; 1. Çekimsiz sözlerin zarflık kullanımı, 2. Çekimli sözlerin zarflık kullanımı, 3. Çekimli eylemlerin zarflık kullanımı olmak üzere üç yol olduğunu ifade eder (Karaağaç 2013: 884).

"Zarf-fiiller hareket hâli ifade eden fiil şekillerdir (Ergin 1999:338)." Standart Türkiye Türkçesindeki zarf-fiil eklerinin sayıları ve kullanım alanları bellidir. Fakat asıl zarf-fiil ekleri dışında -Ar/-r gibi, -mIş gibi, DAn önce, -DAn sonra vb. çoğu gramer kitaplarında ele alınmayan zarffiil yapıları vardır. Gülsevin, Türkiye Türkçesinde Birleşik Zarf-fiiller adlı çalışmasında Standart Türkiye Türkçesi gramer kitaplarında ele 
alınmayan bu yapılar için kullanılan terimleri tartışmış ve birleşik zarffiller ifadesini kullanmıştır (Gülsevin 2001: 128). Çalışmasında birleşik zarf-fiil başlığında altında ele aldığı konuyu ek+ek yapısında olanlar ve ek+edat yapısında olanlar şeklinde iki grupta incelemiştir. Karagöz, Bafra'da Drama Göçmenleri Ağzında Yaşayan Zarf-fiiller adlı çalışmasında bu tür zarfları aynı şekilde gruplandırır (Karagöz 2013:674679).

Anadolu ağızlarındaki zarf-fiil eki almış fiillerden ve isimlerle edatların oluşturduğu edat gruplarından meydana gelen zarflar farklı yap1 özellikleri gösterir. Leylâ Karahan Anadolu Ağızlarında Kullanılan Bazı Zarf-fiil Ekleri adlı çalışmasında bu tür zarf unsurlarını bir siniflandirmaya tabi tutar. Karahan yazı dilinden k1smen ya da tamamen değişiklik gösteren zarf-fiil eklerini; zarf-fiil eklerinden değişmiş ya da genişlemiş olanlar, sıfat-fiil eklerinden genişlemiş olanlar, isim-fiil eklerinden genişlemiş olanlar, arkaik yapı ve anlam özelliği taşıyan ekler ve diğer zarf-fiil ekleri olmak üzere gruplandırmıştır (Karahan 1996b:205-207).

Tokat ağzındaki yazı dilinden farklı birleşik zarf-fiil unsurlarını eklerin birleşmesi ve genişlemesiyle oluşanlar ve edatların eklerle birleşmesiyle oluşanlar olmak üzere iki başlık altında ele almak mümkündür.

\subsection{Eklerin Birleşmesi ve Genişlemesiyle Yapılan Zarflar}

“Türkçede zarf ve edatlar türeten özel ekler yoktur. Bu sebeple dil, başka gramer ögelerinden faydalanmak suretiyle bu ihtiyacı karşılama yoluna gider (Korkmaz 1994: 57)." Standart dilde ortaya çıkan bu yapıların Anadolu ağızlarında da örnekleri çoktur.

Tokat ağzında fiilimsilerin (zarf-fiil, sıfat-fiil, isim-fiil) kendi türünden ya da başka eklerle birleşip kalıplaşması sonucunda ortaya çıkmış çok sayıda örnek vardır.

\subsubsection{Zarf-Fiil Eklerinin Genişlemesiyle Oluşanlar}

\section{-ArAkdAn}

Hakkında Ergin, Korkmaz, Bang, Deny ve Yüce'nin hakkında görüş bildirdiği (Cin 2012:186-187) -ArAk zarf-fiil ekinin -A zarf-fiiliyle +rAK karşılaştırma ekinden meydana geldiği kabul edilmektedir (Durmuş 2012: 51). Bu zarf-fiil ekinin -DAn ayrılma hâl ekiyle birleşerek oluşturduğu ArAktAn şekli standart Türkiye Türkçesinde özellikle şiir dilinde kullanılır. Bazı Anadolu ağızlarında $-A r A k t A$ ve $-A r A k t A n A$ şekillerine de rastlanır (Argunşah 2011:61). 
Bu ek Tokat ağzında -dAn eki tonlu biçimde -ArAkdAn şeklinde yaygın olarak kullanılır: gelerekden, söyleyerekden, alarakdan, bakarakdan $v b$.

$-k A n A$

Standart Türkiye Türkçesindeki -ken zarf-fiil ekinin "a" pekiştirici morfemiyle genişlemesi sonucunda ortaya çıkmıştır (Karahan 1996b:216). Tokat ağzında -kAnA şeklinde ünlü uyumuna uygun olarak kullanılır: gelükene, söylerkene, bakarkana, sorarkana vb.

\section{$-m A d A n A$}

Korkmaz, Eski Türkçe döneminden beri kullanılan -mAdAn zarf-fiil ekinin -matı/-meti, -matın/-metin, -madın/-medin gibi tarihi lehçelerindeki varyantlarına dikkat çekmiş, Eski Anadolu Türkçesindeki -madın/-medin şeklinin Anadolu bölgesinde, ekteki -dın/-din ögesinin, ayrılma hâli eki dın/-din ve benzer öteki şekiller ile karıştırılması yüzünden zamanla madın /-medin>-madan/-meden değişimine uğradığını ifade etmiştir (Korkmaz 1969:260-269).

-mAdAn eki Tokat ağzında -A ekiyle genişleyerek -mAdAnA şeklini almıştır. Kullanımı oldukça yaygındır: alışmadana, bakmadana, yemedene, görmedene $v b$.

\section{-IncIyA/-UncUyA}

Türkçedeki -IncA zarf-fiil ekinin Tokat ağzında son ünlüsünün daralması söz konusudur. Bölgedeki -IncI, -UncU zarf-fiil eklerine -A yönelme hâl ekinin eklenmesiyle ortaya çıkarmıştır. Düzlük yuvarlaklık uyumuna uygun olarak kullanılır: gelinciye, görüncüye, alıncıya, soruncuya vb.

\section{-IncIyadar/-UncUyadar}

-IncIyA/ -UncUyA zarf-fiilinin kadar edatıyla birleşmesiyle ortaya çıkmıştır: alıncıyadar, soruncuyadar, gelinceyadar, görüncüyadar vb.

\subsubsection{Sıfat-Fiil Eklerinin Genişlemesiyle Oluşanlar}

\section{-DUkCAm}

-DUk ekinin -CA eşitlik hâliyle kalıplaşması sonucunda oluşan -DUkCA zarf-fiil eki Türkçede yaygın olarak kullanılan bir zarf-fiil ekidir. Dil bilgisi kitaplarında genellikle bu eke yer verildiği görülür.

Anadolu ağızlarında -dıkca, -dikce, -dukça, -dükçe, -duhca, -duhç̧a gibi örnekleri vardır (Üstüner 2000: 111).

Tokat ağzında ünlüsü yuvarlak olan -DUk sıfat-fiil ekinin -A eşitlik ekiyle birleşmesinden oluşan -DUkCA Zarf-fiili iyelik birinci teklik şahıs 
ekiyle -DUkCAm şeklinde genişlemiştir. O söyledükcem ben güldüm. Sen böyle gonuşdukcam...

\section{-DUkCAmA}

-DUkCAm zarf-fiil ekinin -A yönelme hâli ekiyle genişlemiş şeklidir: aldukcama, bakdukcama, söyledükceme, gördükceme vb.

\section{-DUkCAmAsI}

Tokat ağzında -DUkCAmA zarf-fiili -sI iyelik 3. teklik şahıs ekiyle yeniden bir genişlemeye uğramıştır: ă̆naddukcaması, sordukcaması, dedükcemesi, yedükcemesi $v b$.

\section{-DUklUyUn}

Anadolu ağızlarında -DUklAyIn şeklindeki zaman bildiren zarf-fiil ekinin örnekleri vardır. "Denizli bölgesinde keri edatına (bulduklayın keri) bağlanarak kullanılır (Üstüner 2000: 113).”

-DUk sıfat-fiili ile Eski Anadolu Türkçesinde vasıta eki -n’yi ihtiva eden ve birleşik edatlarda teşbih bildiren -lAyIn ekinin (Timurtaş: 1994:75) birleşmesiyle oluşmuş bir zarf-fiildir. Tokat ağzında -lAyIn eki sabahleyin, akşamleyin gibi belli kelimelerle sınırlıdır. Buna rağmen Eski Anadolu Türkçesindeki -lAyIn ekinin eşitlik fonksiyonuyla -DUk sıfatfiiline eklenerek zarf-fiil yapması yaygındır. Tokat ağzında -DUklUyUn şeklinde "-dıkça, -dığında" anlamında kullanılır. -DUk sıfat-fiil ekinin ünlüsünün yuvarlak olması -lAyIn, ekindeki ünlülerini yuvarlaklaştırmıştır: gonuşdukluyun, aldukluyun, geldüklüyün, dedüklüyün vb. Böyle dedüklüyün geri döndü. "Böyle söyleyince geri döndü."

\section{$-A n A c A$}

-AnAcA zarf-fiili -An sıfat-fiil ekinin -A yönelme hâl eki ve -cA, eşitlik ekiyle birleşmesinden oluşmuştur (Karahan 1996b:221). Tokat ağzında kullanımı yaygındır: satanaca, alanaca, gelenece, diyenece $v b$.

\section{-Anadar/-Anacar}

Bu ek -An sıfat-fiil eki ile bu eke -A yönelme hâl ekiyle bağlanan kadar edatının eklenmesiyle ortaya çıkmıştır. Edatın ilk ünsüzü düşer ve iç seste $\mathrm{d}>\mathrm{c}$ değişmesi görülür: soranadar, alanadar, gelenadar, görenadar, soranacar, alanacar, gelenacar, görenacar $v b$. 


\section{$-A \operatorname{sIyAcA}$}

Bu ek -AsI sıfat-fiil ekiyle -A yönelme hâl eki ve -CA eşitlik ekinin birleşmesiyle ortaya çıkmış bir zarf-fiildir (Karahan 1996b:223): gelesiyece, göresiyece, alastyaca, bakastyaca $v b$.

\section{-AsIyadar/-AsIyacar}

-AsI sıfat-fiil ekiyle bu eke -A yönelme hâliyle bağlanan kadar edatından meydana gelmiştir: Edatın ilk ünsüzü düşer ve iç seste $\mathrm{d}>\mathrm{c}$ değişmesi görülür: gelesiyadar, göresiyadar, alasıyadar gelesiyacar, göresiyacar, alaslyacar $v b$.

\section{$-U /-m A z$}

Korkmaz, -r(-Ar, -Ir, -Ur )...-mAz yapısındaki zarf-fiili Oğuz ve Kıpçak lehçesine özgü bir şekil sayar ve bu ekin asıl fiildeki hareketin, zarffiildeki hareketin hemen arkasından gerçekleştiğini bildiren bir işlevi olduğunu ifade eder (Korkmaz 2003:1036).

Tokat ağzında dar ünlülü geniş zaman eklerinde $-I r /-m A z$ zarf-fiilinin $\mathrm{r}$ düşmesi ve ünlü yuvarlaklaşması sonucunda $-\mathrm{U} /-\mathrm{mAz}$ şeklinde kullanıldığ1 görülür; alu almaz, gelü gelmez, görü görmez, diñlenü diñlenmez $v b$.

\section{$-m A m I s$}

- $m I$ I̧//- $m U_{S ̧}$ sıfat-fiili olumsuzluk eki $(-m A)$ ile $-m A m I s ̧$ şeklinde zarf-fiil göreviyle kullanılmaktadır. Başka Anadolu ağızlarında da rastlanan bu şekil -mAdAn ekine yakın bir anlamda kullanılır.

Sormamış duramaz. Görmemiş anlayamaz. Duymamış edemez. Almamış gitmez. Çalışmamış duramaz.

\section{-mAmIşIñ}

- $m I$ Ş/- $m U_{S ̧}$ sıfat-fiil eki ile $-m A$ olumsuzluk ekinin birleşmesiyle oluşan $m A m I s ̧$ eki üzerine $-\tilde{n}$ ekini alarak genişlemiştir.

-mAmIş zarf-filinin sonundaki - $\tilde{n}$ eki Anadolu ağızlarında isim-fiil eklerinden genişleyen -ışın/-işin zarf-fiilde görülen - $n$ ekine benzer. Karahan, -ışıı/-işin eki hakkında "-ış,-iş̧ fiilden isim yapma ekiyle - $n$ vasıta ekinden meydana gelmiştir” şeklindeki izahı hatırlatmış, - $n$ ekinin fonksiyon bakımından -ınca, -ince ekine benzediğini ifade etmiştir (Karahan1996b:226-227).

Tokat ağzında -mAmIşıñ şeklinde kalıplaşmış zarf-fiil anlamca -mAdAn ekine yakındır. Ben görmemişiñ söyleyemem. "Ben görmeden söyleyemem." Çalışmamışıñ para gazanılmaz. "Çalışmadan para 
kazanılmaz." Ona yardım etmemişiñ bu iş bitmez. "Ona yardım etmeden bu iş bitmez."

\subsection{3. İsim-Fiil Eklerinin Genişlemesiyle Oluşanlar}

\section{$-m A y \operatorname{In} A n$}

$-m A$ isim-fiil ekinin üzerine bölge ağzındaki $-\operatorname{InAn}$ vasıta ekinin getirilmesiyle oluşan bir zarf-fiil ekidir. Bölgede "-mak ile, -makla beraber" anlaminda kullanılır: Dutmayınan firlatd. Vurmayınan yere düşürdü.

\section{$-m A \operatorname{In} A$}

$-m A$ isim fiil eki, $-s I$ iyelik 3. teklik şahıs eki ve $-A$ yönelme hâl eklerinin birleşmesiyle oluşmuş şekildir: yanlamasına, düzlemesine, enlemesine, diklemesine vb. Göre, beri, doğru edatlarıyla birlikte kullanıldığ 1 da olur: enlemesine doğru, yanlamasına beri, gerilemesine doğru "geri tarafa doğru" vb.

\subsubsection{Kip Eklerinin Soru Ekiyle Kalıplaşmasıyla Oluşanlar}

\section{$-d I m m I$}

Görülen geçmiş zaman eki $-d I /-d U$ ile $m I / m U$ soru ekinden kurulu şekil olup olağan işlevi ile geçmiş zamana bağlı bir soru cümlesi oluşturur. Ancak bazı durumlarda soru özelliğini kaybedip zarf-fiil olma özelliği kazanmıştır (Korkmaz 2013: 1037).

Bölgede zarf yapan $-D I$, $-D U m I m U$ kalıbında, görülen geçmiş zaman kip eki üzerine pekiştirme göreviyle " $m$ " morfeminin getirilmesi söz konusudur. Anlamı $-r /-m A z$ ve $-\operatorname{IncA}$ ekiyle hemen hemen aynidir: vardım mı "varır varmaz", girdim miyidi "girince, gerer girmez" vb. Ben içeri girdim miyidi ayă̆a kalkar.

\subsubsection{Arkaik Özellik Taşıyanlar}

\section{-gIn}

Tokat ağzında bir arkaik şekil olan - gIn eki, anlamca Eski Türkçedeki gInCA ekine benzer olarak Ar/-mAz, -mAklA birlikte, -IncA anlamlarında zaman bildiren zarflar yapmaktadir.

Süleyman amca namazı gılıngın çayıra dikilüdü. "Süleyman amca namazı k1lar k1lmaz çayıra giderdi.”.

Eski Türkçede -gıç̧a zarf-fiili, "-1nca, -dığı müddetçe, -1ncaya kadar manasına gelen cümle belirleyicisi olarak vazife gören bir ektir. İsme gelen diğer şekil unsurlarıyla genişletilebilir (Gabain 1988: 87). 
Uygurcada yaygın bir zarf-fiil olmayıp hareket hâlini ifade etmektedir. Zaman ve hâl zarfı yapmada kullanılır. Ekin yapısıyla ilgili görüş bildiren Gabain, Brockelmann, Ergin, Tekin gibi araştırmacılar bünyesindeki -CA eşitlik hâline dikkat çekmişlerdir (Eraslan 2012: 412).

Çağataycada asıl hareketle aynı zamanda veya asıl hareketin sonunda olan bir olayı belirtmek için kullanılan -gUnCA (Karaağaç 1988: 112), Kıpçak Türkçesinde Eski Türkçedeki anlamıyla (-gınça <g-1-n-ça '1ncaya kadar') kullanılmaktadır (Karamanlıŏglu !994: 146).

Karahan, -ışgın/-işgin zarf-fiilinin izahını yaparken "-gın, -gin eki bir isim ekinden sonra geldiği için fiilden isim yapma eki olamaz" ifadelerini kullanmış ve Yüce'nin “-ışgın/-işgin ekinin eski şeklini şu veya bu şekilde koruyabilen bir ek olabileceği veya -ışın/-işin ekinin -ken zarf-fiil ekine analoji ile değişmiş olabileceği" düşüncesini aktarmıştır (Karahan 1996b: 227). Karahan, ekin -ışkıma, -işkime şeklinin de olduğunu bildirerek (<1Ş-1-k-1-n) yapısındaki $-\mathrm{k}$ ve $-\mathrm{n}$ eklerinin başka zarf-fiillerde de bulunan pekiştirme ekleri olabileceğini ifade etmiştir.

Tokat ağzındaki -gIn ekinin -1şgın/-işgin ekindeki gibi bir isime gelmediği anlaşılmaktadır. Süleyman amca namazı gılıngın çayıra dikilüdü. örneğinde -gIn fiile gelir. Ekin tarihi lehçelerdeki $-g I n+C A$ ekiyle anlam ve yapı bakımından benzerliği dikkat çekicidir.

\subsection{Edatların Eklerle Birleşmesiyle Yapılan Zarflar}

Zarf olarak kullanılan birer fiil şekli olan zarf-fillerin edatlarla ortaklaşan özellikleri vardır (Korkmaz 1994: 57). Bazı edatların isim unsurlarına eklerle birleştiği, bazılarının da ekleştiği ya da ekleşmeye müsait olduğu bilinmektedir.

Tokat ağzında; -A beri, -A deyin, - $A$ gedük, -A gene, - $A$ öte, - $A$ öteri, - $A$ kadar, -DAn arl, -DAn aşa, -DAn beri, -DAn gene, -DAn öteri, -DAn öñüe, -DAn soñuna, -DAn yana -InAn barabar, gibi edatlar yönelme, bulunma, ayrılma, yön, ilgi hâl ekleriyle zarf görevi yapar.

\section{$-A$ beri}

Eski Türkçedeki berü edatı Tokat ağzında Batı Türkçesine uygun biçimde beridir. Bölgede isimlere $-A$ ve $-D A n$ hâl ekleriyle bağlanır.

Yönünü eve beri çevür. Baña beri bak. "Benden taraf bak." Arabanıñ öñüne beri durma. Dereniñ yanına beri yaklaşma. Bu tarafa beri geldiler.

\section{$-A$ deyin}

Eski Türkçede görülen $t i-y-i-n\rangle$ deyin edatı $t i$ - fiilinden (<ET ti->di-/de-) -i zarf-fiil ekiyle kalıplaşmıştır (Hacıeminoğlu 1992:198). Deyinin 
bünyesinde - $n$ vasita ekinin kalıplaşması da söz konusudur (Korkmaz 1994: 69). Tokat ağzında "için” anlamlarında kullanılmaktadır. Bana deyin yollamış. "Benim için yollamış." Sana deyin vermiş. "Senin için vermiş."

Deyin edatı -mIŞ/-mUş deyin, -DI/-DU deyin -Ar deyin, -AcAk deyin şeklinde çekimli unsurlarla da kullanılır. Gelmiş deyin, görmüş deyin, geldi deyin, gördü deyin, pahaluymuş deyin, güzelmiş deyin, böyleymiş deyin $v b$.

\section{-A gedük}

Tokat ağzındaki gedük edatı Divânu Lügâti’t-Türk'teki kert- kertik, kertük sözleriyle ilgilidir (<ET kert- fiilinden kert-ü-k>gedük). "Kert-: (ağaç) kertmek; (boyun) kertmek, küçük düşürmek. Kertik: ekmek ve benzeri şeyleri hesaplamak için tahtaya oyulan kertikler(kesikler). Kertük: kertik, tahtada kertme (Ercilasun-Akkoyunlu, 2014:705)." Yeni Tarama Sözlüğü'nde gedük (gedik) için; “1.Eksik, noksan, ihtiyaç. 2. Çatlak, yarık, gedik." anlamları verilmiştir (Dilçin 1983: 90).

Tokat ağzında gedük, edatı $b u$ ve $o$ zamirleriyle birlikte edat grubu yapisında zarflar meydana getirir. Bu gedük "bu kez", o gedük "o sefer".

Bu gedük konuşmadl. "Bu kez konuşmad1." Bu gedük affet. "Bu sefer affet." Bu gedük dur. "Bu kez dur.". O gedük böyle dedi. "O anda böyle dedi."

\section{-A gene}

Bölgede tek başına zarf olarak da kullanılan genenin -A yönelme hâl eki almış kelimelerle birlikte "-e doğru" anlamında edat grubu şeklinde zarf yapması söz konusudur: Yakına gene gel. Uză̆a gene dur. Dikine gene git. Bu tarafa gene yürü. vb.

Yön gösterme ekinin kalıplaştığı isimlerle de kullanılır: Beri gene gel. Içeri gene girdiler. Dışarı gene uzatdı, Geri gene düşdüm. Ileri gene dur.

Bazı isimlere eksiz bağlanarak zarf yapar: öte gene, tek gene, böyle gene, adam akıllu gene, çabuk gene, rahat gene $v b$.

\section{-A kadar (-A acar /-A adar)}

Tokat ağzında isimlere - $A$ yönelme hâl ekiyle bağlanan kadar edatının bazı ses olayları sonucunda adar, acar gibi şekillere dönüştüğü görülür: yapanadar, söylüyenadar, gidenadar, diyenadar, yapanacar, söylüyenacar, gidenacar, diyenacar vb. 


\section{-A öte}

Codex Cumanicus'ta işlek zarf-fiilliğini kısmen muhafaza eden öte 'geçerek' (öt-e<öt- 'geç') kelimesi Eski Anadolu metinlerinde hem zaman hem de yer zarfi hâlinde kalıplaşmıştır. Osmanlıca ve Anadolu ağızlarında öte "öbür taraf” zarf durumunu muhafaza etmiştir (Korkmaz 1994: 60).

Tokat ağzında “-e doğru” anlamında yön zarfı olarak kullanılır. Standart Türkiye Türkçesindeki -DAn öte şeklinin yanı sıra isimlere -A yönelme hâli ekiyle bağlandığını gösteren örnekler vardır: Buña öte, şuña öte, oña öte, bu taraflara öte, önüne öte, ardına öte, yanına öte, vb.

\section{-A öteri}

Öteri Divânu Lügâti’t-Türk’te geçmemektedir. Derleme Sözlüğü’nde Urla/İzmir, Kastamonu/Taşköprü ve Samsun ağızlarında “ötrü”ye atıf yapılarak "dolayı" anlamında kullanıldığı belirtilmiştir (DS, C.IX, 1977: 3358). "Türkmencede öteri (öt-er-i) şekli vardır. (Korkmaz 1994: 64)."

Öteri Tokat ağzında -A öteri şeklinde “-e doğru” anlamında zarf olarak kullanılmaktadır: tarlalara öteri, eve öteri, buña öteri, oña öteri, yanına öteri vb. Öterinin "öte" anlamında tek başına yön zarfı olarak kullanılması da söz konusudur: Öteri git. Öteri dur.

\section{-DAn arı}

"Eski Türkçede bulunmayıp orta Türkçe devresinde görünmeye başlayan arı edatı "-e doğru, -den öte, -den ileri, -den" anlamlarını verir. Kıpçak ve Sibirya şivelerinde ve Anadolu ağılarında rastlanmaktadır (Hacieminoğlu, 1992:6)." "Bu edatın narı/naru ile münasebeti düşünülebilir." diyen Hacıeminoğlu, çıkma hâli ile -dan arı şeklinde kullanıldığı zaman -da narı şeklinde yanlış heceleme neticesinde narı edatının ortaya çıkmış olabileceğini düşünmüştür. Hacıeminoğlu, J. Deny'nin arl-naru münasebetiyle ilgili inaru>naru>narl $>$ arı şeklindeki açıklamasına ve Brockelmann'ın arı edatını naru bahsi içinde ele alıp izah yapmamasına işaret eder (Hacıeminoğu, 1992:6).

Tokat ağzında bu edat; yoldan_art, burdan_arı, hepden art gibi örneklerde görülür.

\section{-DAn aşa}

A. von Gabain aşa edatını aş-fiilinin zarf-fiil şekli olarak izah eder. "Bu edat Eski Türkçe ve Batı Türkçesi sahalarında çekim edatı olarak kullanılmıştır. (Hacıeminoğlu, 1992:9).” Eski Türkçedeki aşa 'öte, ötede’ <aş-a<aş- 'aşmak' (Gabain 1998: 93) edatı isimlerin yalın hâlinden sonra 
kullanılmaktadır (Korkmaz 1994:63). Tokat ağzında -DAn ekiyle kullanıldığ örnekler vardır.

Bereketlü'ye burdan aşa gidersiñ. "Bereketli'ye buradan geçerek gidersin."

\section{-DAn beri}

Evden beri geldi. "Ev tarafından geldim", Yamaçdan beri yürü. "Yamaç yönüne doğru yürü."

Bölge ağzında -A beri ve -DAn beri edatları üzerine gene edatı getirilerek de kullanılır: Pek klylya beri gene durma. Klyıdan beri gene dur.

\section{-DAn öñ̈̈ne /-DAn soñuna}

-DAn sonra ve -DAn önce yapısı içinde yer alan sonra ve önce kelimeleri söz dizimindeki anlam özellikleri ne olursa olsun çekim edatı olarak değerlendirilmektedir (Karahan 2011: 274). Ancak bu kelimeler isimlerle aralarına çok, az, biraz, hemen gibi derecelendirici unsur alabilmektedir (Karahan 2011: 274). Bu edatlar Tokat ağzında öñ̈ne, soñuna şeklinde kullanılır: Senden öñüne gitdiler.

\section{-DAn yana (yanna, yanni)}

Taraf, cihet, yön anlamındaki yan Batı Türkçesinde kullanılan bir edattır (Hacıeminoğlu, 1992:107). Tokat ağzında yan edatının yanı, yannı, yana, yanna şekilleri kalıplaşmıştır: evden yana, evden yanna, camıdan yana, camıdan yanna $v b$. İşaret zamirlerine ve bazı isimlere eksiz eklendiği örnekler de vardır: o yanı, bu yanı, o yanni, bu yannı, ev yana, vb. Çocuklar bu yanı gittiler. Misafirler ev yana gitdiler.

\section{-InAn barabar}

Tokat ağızlarında ile edatı vasıta ekinin görevini yapmak için -InAn şeklinde kullanılmaktadır. Bu ekin bünyesinde ile edatılla birlikte kelimeler arasında vasıta ve beraberlik ilişkisi kuran, kalıplaşmış $-n$ vasıta eki bulunmaktadır. Korkmaz - $n$ vasıta ekinin kalıplaşmasında türlü alan ve metinlerde başka ek ve edatların kullanılmış olmasının da etkili olduğu belirtmiştir (Korkmaz 1994: 19).

Tokat ağzında ünlüleri kalın olarak kullanılan barabar edatı -InAn ekiyle birlikte -InAn barabar zarfinı meydana getirir: Onlarinan barabar, seniñinen barabar, vurmaslyınan barabar, gelmesiynen barabar $v b$. 


\section{Sonuç}

Türkiye Türkçesinin diğer ağızlarında olduğu gibi Tokat ağzında da $e k+e k$ ve ek+edat yapısında olan zarf unsurları vardır. Bu zarf unsurlarının $e k+e k$ yapısında olanlarının daha çok zarf-fiillerin ve sıfatfiillerin genişlemesiyle oluştuğu görülür.

İsim-fiillerin genişlemesiyle oluşan zarf yapılarında daha çok $-m A$ isim fiilinin tercih edildiği anlaşılmaktadır. Zarf-fiil yapılarında dikkat çeken en önemli unsur bu yapıların genişlemeye müsait olmasıdır. Genişlemedeki temel sebep zarfların fiile yakın, vurgulu unsurlar olmalarıdır. Eklerle genişlemiş zarf-fiillerde daha çok $-A$ yönelme, $-D A n$ bulunma, $-C A$ eşitlik, - $n$ vasita ekleri ve $-m,-I,-s I$ iyelik ekleri kullanılmıştır.

Bölge ağzında kadar edatının -Inclyadar/-UncUyadar, -Anadar/-Anacar, -AsIyadar/-AsIyacar gibi zarf-fiil yapıları içerisinde kaynaşma eğilimi olduğu görülür.

Tokat ağzındaki zarf yapıcı unsurlar arasında yer alan arkaik -gIn eki, ünlü yuvarlaklaşmalarının görüldügü -DUklUyUn eki ve arı, aşa, deyin, gedük, gene, öte, öteri, yan gibi arkaik edatlar tarihi lehçelerle bölge ağzının ilişkisi bakımından dikkat çekicidir.

Çeşitli ek ve edatlarla yapılmış zarf-fiil unsurlarının Tokat ağzında başka varyantlarının bulunması da ihtimal dahilindedir. Türkçenin ağızlarındaki bu tür yapıların tespit edilmesi ağızların şekil özelliklerinin ortaya çıkması açısından önemlidir.

\section{Kaynaklar}

Argunşah M. (2011), "Türkçede Zarf-Fiil Eklerinin Durum Ekleriyle Kalıplaşması", Turkish Studies, Volume 6/1, Winter. Turkey.

Banguoğlu, T. (1995), Türkçenin Grameri, TDK Yay., Ankara.

Caferoğlu, A. (1944), Tokat ve Sivas Ağızlarından Toplamalar, İstanbul.

Cin, A. (2012), “-ArAktAn Ekinin Kullanımı ve Yapısı”, SDÜ Fen Edebiyat Fakültesi, Sosyal Bilimler Dergisi, Say1: 25, Isparta.

Demir, N. (2006), Tokat ve Yöresi A ğızları, Gazi Kitabevi, Ankara.

Dilçin, C. (1993) Yeni Tarama Sözlüğü, TDK., Yay, Ankara.

Durmuş, O. (2012), “\{-(y)ArAK\} Zarf-Fiil Ekinin Kökeni Üzerine”, Türkbilig, Sayı: 23.

Eraslan, K. (2012), Eski Uygur Türkçesi Grameri, TDK., Yay, Ankara. 
Ercilasun Ahmet. B-Akkoyunlu, Z. (2014) Kâşgarlı Mahmud Divânu Lügâti't-Türk, Giriş-Metin-Çeviri-Notlar-Dizin, TDK Yay., Ankara.

Gabain, Annamarie von (1988), Eski Türkçenin Grameri, TDK Yay., Ankara.

Gülensoy, T.-Alkaya, E. (2000), Türkiye Türkçesi Ağızları Bibliyografyası, Akçă̆ Yay., Ankara.

Gülsevin, G. (2001), “Türkiye Türkçesinde Birleşik Zarf-fiiller”, Afyon Kocatepe Ü., Sosyal Bilimler Dergisi, C.II, Sayı: 2, Afyon.

Hacıeminoğlu, N. (1992), Türk Dilinde Edatlar, MEB. Yay., Ankara.

Karaağaç, G. (2013), Dil Bilimi Terimleri Sözlüğü, TDK Yay., Ankara.

Karaağaç, G. (1988), Çă̆atayca El Kitabı, İ.Ü. Edebiyat Fak. Yay., İstanbul.

Karagöz, İ. (2013), “Bafra'daki Drama Göçmenleri Ağzında Yaşayan Zarf-filler”, Leylâ Karahan Armağanı, Akçă̆ Yay., Ankara.

Karahan, L. (1996a), Anadolu Ağızlarının Sınıflandırılması, TDK Yay, Ankara.

Karahan, L. (1996b), “Anadolu Ağızlarında Kullanılan Bazı Zarf-Fiil Ekleri”, Türk Kültürü Araştırmaları Prof. Dr. Zeynep Korkmaz'a Armă̆an, TKAE Yay., Ankara.

Karahan, L. (2004), Türkçede Söz Dizimi, 7. Baskı, Akçă̆ Yay., Ankara.

Karahan, L. (2011), "Zarf-fiil Eklerinde Genişleme Eğilimi ve -sA(r) Ekinin Yapısı" Türk Dili Üzerine Incelemeler, Akçağ Yay., Ankara

Karamanlığlu, Ali F. (1994) Kıpçak Türkçesi Grameri, TDK Yay., Ankara.

Korkmaz, Z. (1994), Türkiye Türkçesi Grameri Şekil Bilgisi, TDK Yay., Ankara.

Korkmaz, Z. (2003), Türkçede Eklerin Kullanılış Şekilleri ve Ek Kalıplaşması Olayları, TDK Yay., Ankara.

Korkmaz, Z. (1969), "Türkiye Türkçesindeki -madan/ meden, -madın<medin Zarf-Fiil (Gerundium) Ekinin Yapısı Üzerine”, Türkoloji Dergisi II/I, Ankara.

Sümer, F. (1999), Ŏguzlar (Türkmenler) Tarihleri, Boy Teşkilatı, Destanları, 5. Bask1, İstanbul. 
Turan, O. (1993), Selçuklu Zamanında Türkiye, Boğaziçi Yay., 3. Bask1, İstanbul.

Türk Dil Kurumu (1977), Türkiye’de Halk A ğzından Derleme Sözlüğü, C. IX, TDK Yay., Ankara.

Üstüner, A. (2000), Anadolu Ağılarında Sıfat-fiil Ekleri, TDK Yay., Ankara.

Sözlü Kaynaklar: Süleyman Öztürk, Yaşar Şimşek, Mehmet Kocabay, Metin Avşar, Şükrü Eraslan, Hamide Öztürk. 